\title{
REVISIÓN
}

\section{Fate of Neospora-seropositive animals: An opinion}

\author{
DADIN P. MOORE *
}

\begin{abstract}
Neospora caninum is an abortive protozoon in cattle, which causes severe economic losses worldwide. Chronically infected cattle however develop immune responses protecting against further Neospora induced abortions. Controversy about losses other than abortion in Neospora-infected cattle still exists. Although, culling of seropositive animals has been recommended as a strategy for reducing economic losses due to $\mathbf{N}$. caninum, there is no guarantee of escaping postnatal infection and abortion storms by having a "Neospora-sterile herd". An inactivated vaccine has been demonstrated to reduce abortion rates. Antibodies generated by natural infection can not presently be differentiated from those induced by vaccination; however, since maternal antibodies disappear by 6 months in calves born to vaccinated heifers, a test-and cull strategy could be performed in replacement heifers before breeding and vaccination. This review article discusses control strategies for Neospora-infection in cattle, and provides suggestions for further research.
\end{abstract}

Key words: Bovine, Immunology, Neospora caninum.

\section{INTRODUCTION}

Neospora caninum (N. caninum) is an abortive protozoon in cattle, which causes severe economic losses worldwide ${ }^{1}$. Although horizontal transmission can introduce the disease in to a naïve herd, vertical transmission is considered the most common mode of infection ${ }^{2}$. Seropositiveanimals are more likely to abort than seronegative ones $^{1}$; however, most infected dams transmit the parasite to their offspring without clinical signs ${ }^{1,2}$.

As in other infections, an "equilibrium relationship" between host and parasite may be found in neosporosis. One result of such an equilibrium relationship is the vertical transmission of the parasite through multiple generations. In contrast, an imbalance between host and parasite (with damage to the host) can lead to abortion ${ }^{3-5}$. To arrive at the best strategy for reducing reproduction and production losses due to Neospora-infection some questions must be considered:

1) What are the potential advantages and disadvantages for infection-free compared to infected herds?

2) Are there other economic losses besides Neospora-abortion that justify the culling of Neospora-seropositive animals?

3) Is vaccination a good strategy?

Each particular epidemiologic and economic situation can have its own rationale; nevertheless, the questions mentioned above can be partially answered based on existing evidence.

Consejo Nacional de Investigaciones Científicas y Técnicas (CONICET), Buenos Aires, Argentina.

* Address: Sanidad Animal, Instituto Nacional de Tecnología Agropecuaria (INTA), CC 276 (7620) Balcarce, Argentina.

E-mail address: dadinprandomoore@hotmail.com 


\section{Infected herds versus non-infected herds}

In an endemic situation, a herd with high prevalence of $N$. caninum can have severe reproductive losses since $N$. caninum is a primary pathogen in cattle ${ }^{1}$. The annual abortion rate can be as high as $10.6 \%$ to $17.3 \%{ }^{6}$. However, although vertical transmission is going to be a frequent fact in an infected herd with high prevalence, the risk of "an abortion storm" caused by a new Neospora-exposure could be lower than in a naïve herd. It was demonstrated that chronically infected beef cows are less likely to abort or give birth prematurely than cows lacking a previous exposure to the protozoa, during an outbreak of neosporosis 7 . The development of immune mechanisms against Neospora-abortion has been suggested because the incidence of abortion decreases with the number of pregnancies $^{8-11}$. In addition, experimental evidence of protective immune responses against abortion and vertical transmission has been shown in chronically infected cattle ${ }^{12}$ and naïve cattle inoculated with live $N$. caninum tachyzoites prior to mating ${ }^{13}$, respectively.

\section{Performance of infected cattle}

The economic impact of bovine neosporosis, including stillbirths, neonatal mortality, early fetal death, infertility, increased culling, reduced value of breeding stock and reduced milk production, was described ${ }^{14}$. However, there is continuing controversy about losses other than abortion in Neospora-infected cattle. For dairy cattle, two studies have demonstrated that $N$. caninum seropositive cattle produce less milk than uninfected cows ${ }^{15,16}$. In contrast, seropositive cows produced more milk than seronegative cows ${ }^{17}$. Finally, no significant differences in milk production were found ${ }^{18}$. On the other hand, an improved udder health was associated with a $N$. caninum-positive serostatus in cows from farms without a recognized abortion problem ${ }^{19}$. In calves, no adverse effect of congenital infection on calf survival up to 3 months was reported ${ }^{20}$. Moreover, a significant survival advantage for congenitally infected calves over non-infected calves was found in one of two dairy herds in a study $^{20}$.

For beef cattle, significant reductions in postweaning weight gain, carcass weight, and economic return were observed in seropositive calves in a feedlot ${ }^{21}$, as well as significant reductions in short-term weight gain and feed efficiency in post-weaning steers ${ }^{22}$. However in another study, pre-weaning performance of infected and uninfected beef calves were similar ${ }^{23}$. Further investigation is needed to determinate whether the culling of seropositive cattle is justified because of production losses (milk production, post-weaning weight gain, carcass weight, short-term weight gain and feed efficiency) associated with Neospora-infections.

\section{Control strategies}

By using computerized models, economic losses were described in beef cow-calf herds ${ }^{24,25}$. The return on fixed assets, as determined by subtracting variable costs from the annual income, was reduced by endemic Neosporainfection ${ }^{25}$. Three control strategies (culling females that fail to calve, selling seropositive females and purchasing seronegative replacements, and excluding the daughters of seropositive dams as potential replacements) were also evaluated, and the removal of female offspring born to seropositive dams was the only economically beneficial strategy ${ }^{25}$. The infection level in a dairy herd with low postnatal infection and predominantly congenital transmission was also reduced by culling seropositive animals ${ }^{26}$. Nevertheless, there is no guarantee of minimizing the risk of postnatal infection and abortion storms by having a "Neospora-sterile herd". Epidemic situations caused by primary Neospora-exposure are generally associated with high rates of abortion $^{7,27,28}$. Extreme strategies should be adopted in order to prevent horizontal transmission in a seronegative herd ${ }^{2,29}$ since many potential vectors or non-recognised host species could be involved in the life cycle of $N$. caninum and no proven methods are available to prevent postnatal infection. Such strategies could seem difficult to perform under extensive management or in areas where definitive hosts are abundant, but could be done in small herds under confinement. Finally, Neospora-seropositive cows with genetic superiority can remain in the herd as embryo donors, and Neospora free embryos can be obtained by using embryo transfer technology $30-32$.

It has been demonstrated that an inactivated vaccine can reduce abortion rates ${ }^{33}$. In their study the pre-vaccination infection status of the cattle and the degree of exposure post vaccination to 
$N$. caninum were unknown; however the incidence of Neospora-abortion was $11.2 \%$ (49/ $438)$ in vaccinated animals and $20.8 \%(91 / 438)$ in the placebo group. In a recent work similar immune responses (titres of specific antibodies and concentrations of IFN- $\gamma$ ) were observed in naturally infected heifers and heifers inoculated with a killed whole $N$. caninum tachyzoite preparation during the second trimester of gestation $^{34}$. However, it is also known that such inactivated preparations are unable to prevent vertical transmission in cattle ${ }^{35}$.

Antibodies generated by natural infection cannot presently be differentiated from those induced by vaccination. Nevertheless, since maternal antibodies disappear by 6 months in calves born to vaccinated heifers ${ }^{34}$, a test-and cull strategy could be performed in replacement heifers before breeding and vaccination. Furthermore, every pregnant bovine (infected or non-infected) could be vaccinated and its progeny tested serologically before colostrum-intake or after 6 months of age to determinate its infection status. A new vaccine with a specific marker would be a useful tool for differentiating vaccinated from infected animals. Another desirable tool would be a diagnostic technique to detect specific antibodies found only in naturally infected animals. For instance, antibodies against a specific protein of $28 \mathrm{kDa}$ (homolog to BAG5 of Toxoplasma gondii), which is only present in bradyzoites ${ }^{36}$, should be found in naturally infected cattle independently whether is vaccinated or not.

\section{Conclusions}

Although chronically infected cows transmit Neospora-infection vertically, they develop protective immune responses, which contribute to disease control after exposure to Neosporaoocysts. Culling of seropositive animals should be done only if external sources of contamination by Neospora-oocysts are controlled and introduction of infected animals can be prevented. There is still controversy about indirect losses due to Neospora-infections, which are not abortion related. Vaccination appears to be an aid to control of Neosporaabortions, and could also be implemented in association with a test-and cull strategy performed on female replacements before colostrum-intake or after 6 months of age.

\section{RESUMEN}

Neospora caninum es un protozoo que causa abortos en los bovinos produciendo importantes pérdidas económicas en todo el mundo. Existe evidencia reciente que demuestra que los bovinos infectados en forma crónica desarrollan mecanismos inmunes de protección contra el aborto causado por N. caninum. Por otro lado, la existencia de otras pérdidas económicas distintas del aborto es aún tema de controversia. Aunque la eliminación de bovinos seropositivos a la enfermedad a sido recomendado como medida de control sanitaria, un rodeo libre de infección no está exento de sufrir una exposición postnatal y "tormentas" de abortos. La utilización de una vacuna inactivada disminuye la tasa de abortos; sin embargo los anticuerpos vacunales no pueden ser diferenciados de aquellos producidos por infecciones naturales. Considerando que los anticuerpos maternos desaparecen a los 6 meses de vida, la serología de terneras de reemplazo antes del servicio y la vacunación podría ser una posible estrategia de control. Este artículo discute las estrategias de control para limitar la difusión de la neosporosis en bovinos y brinda posibles líneas de investigación.

\section{REFERENCES}

1.- DUBEY J P. Neosporosis in cattle. J Parasitol 2003; 42-56.

2.- ANDERSON M L, ANDRIANARIVO A G, CONRAD P A. Neosporosis in cattle. An Reprod Sci 2000; 6061: 417-31

3.- BUXTON D, MCALLISTER M M, DUBEY J P. The comparative pathogenesis of neosporosis. Trends Parasitol 2002; 18: 546-52.

4.- INNES E A, ANDRIANARIVO A G, BJÖRKMAN C, et al. Immune responses to Neospora caninum and prospects for vaccination. Trends Parasitol 2002; 18: 497-504.

5.- QUINN H E, ELLIS J T, SMITH N C. Neospora caninum: a cause of immune-mediated failure of pregnancy? Trends Parasitol 2002; 18: 391-4.

6.- THURMOND M C, HIETALA S K, BLANCHARD P C. Herd-based diagnosis of Neospora caninum-induced endemic and epidemic abortion in cows and evidence for congenital and postnatal transmission. J Vet Diagn Invest 1997; 9: 44-9.

7.- MCALLISTER M M, BJORKMAN C, ANDERSONSPRECHER R, ROGERS D G. Evidence of point-source exposure to Neospora caninum and protective immunity in a herd of beef cows. J Am Vet Med Assoc 2000; 217: 881-7.

8.- ANDERSON M L, PALMER C W, THURMOND M $\mathrm{C}$, et al. Evaluation of abortions in cattle attributable 
to neosporosis in selected dairy herds in California. J Am Vet Med Assoc 1995; 207: 1206-10.

9.- THURMOND M C, HIETALA S K. Effect of congenitally acquired Neospora caninum infection on risk of abortion and subsequent abortions in dairy cattle. Am J Vet Res 1997; 58: 1381-5.

10.- WOUDA W, MOEN A R, SCHUKKEN Y H. Abortion risk in progeny of cows after a Neospora caninum epidemic. Theriogenology 1998; 49: 1311-6.

11.- DIJKSTRA T, BARKEMA H W, EYSKER M, et al. Evaluation of a single serological screening of dairy herds for Neospora caninum antibodies. Vet Parasitol 2003; 110: 161-9.

12.- WILLIAMS D J L, GUY C S, SMITH RF et al. First demonstration of protective immunity against foetopathy in cattle with latent Neospora caninum infection. Int J Parasitol 2003; 33: 1059-65.

13.- INNES E, WRIGHT S E, MALEY S, et al. Protection against vertical transmission in bovine neosporosis. Int J Parasitol 2001; 31: 1523-34.

14.- TREES A J, DAVISON H C, INNES E A, WASTLING J M. Towards evaluating the economic impact of bovine Neosporosis. Int J Parasitol 1999; 29: 1195200.

15.- THURMOND M C, HIETALA S K. Effect of Neospora caninum infection on milk production in first-lactation dairy cows. J Am Vet Med Assoc 1997; 210: 672-4.

16.- HERNÁNDEZ J, RISCO C, DONOVAN A. Association between exposure to Neospora caninum and milk production in dairy cows. J Am Vet Med Assoc 2001; 219: 632-5.

17.- PFEIFFER D U, WILLIAMSON N B, REICHEL M P et al. A longitudinal study of Neospora caninum infection on a dairy farm in New Zealand. Prevent Vet Med 2002; 54: 11-24.

18.- HOBSON J C, DUFFIELD T F, KELTON D et al. Neospora caninum serostatus and milk production of Holstein cattle. J Am Vet Med Assoc 2002; 221: 1160 -4 .

19.- PEREGRINE A S, DUFFIELD T F, WIDEMAN G. Udder health in dairy cattle infected with Neospora caninum. Prevent Vet Med 2004; 64: 101-12.

20.- PARE J, THURMOND M C, HIETALA S K. Congenital Neospora caninum infection in dairy cattle and associated calfhood mortality. Can J Vet Res 1996; 60: $133-9$.

21.- BARLING KS, MCNEILL JW, THOMPSON JA et al. Association of serologic status for Neospora caninum with postweaning weight gain and carcass measurements in beef calves. J Am Vet Med Assoc 2000; 217: 135660.

22.- BARLING K S, LUNT D K, SNOWDEN K F, THOMPSON J A. Association of serologic status for Neospora caninum and postweaning feed efficiency in beef steers. J Am Vet Med Assoc. 2001; 219: 1259-62.

23.- WALDNER C L. Precolostral antibodies to Neospora caninum in beef calves following an abortion outbreak and associated fall weaning weights. Bov Pract 2002; 36: 81-5.

24.- KASARI TR, BARLING K, MCGRANN J M. Estimated production and economic losses from Neospora caninum infection in Texas beef herds. Bov Pract 1999; 33: 113-20.

25.- LARSON R L, HARDIN D K, PIERCE V L. Economic considerations for diagnostic and control options for Neospora caninum-induced abortions in endemically infected herds of beef cattle. J Am Vet Med Assoc 2004; 224: 1597-604.

26.- HALL C A, REICHEL M P, ELLIS J T. Neosporaabortions in dairy cattle: diagnosis, mode of transmission and control. Vet Parasitol 2005; 128: 231-41.

27.- THILSTED J P, DUBEY J P. Neosporosis-like abortions in a herd of dairy cattle. J Vet Diagn Invest 1989; 1: 205-9.

28.- MCALLISTER M M, HUFFMAN E M, HIETALA S $\mathrm{K}$ et al. Evidence suggesting a point source exposure in an outbreak of bovine abortion due to neosporosis. J Vet Diagn Invest 1996; 8: 355-7.

29.- THURMOND M C, HIETALA S. Strategies to control Neospora infection in cattle. Bov Pract 1995; 29: 603.

30.- BAILLARGEON P, FECTEAU G, PARE J et al. Evaluation of the embryo transfer procedure proposed by the International Embryo Transfer Society as a method of controlling vertical transmission of Neospora caninum in cattle. J Am Vet Med Assoc 2001; 218: 1803-6.

31.- LANDMANN J K, JILLELLA D, O'DONOGHUE P J, MCGOWAN M R. Confirmation of the prevention of vertical transmission of Neospora caninum in cattle by the use of embryo transfer. Aust Vet J 2002; 80: 502-3.

32.- CAMPERO C M, MOORE D P, LAGOMARSINO H, et al. Serological status and abortion rate in progeny obtained by natural service or embryo transfer from Neospora caninum-seropositive cows. J Vet Med B 2003; 50: 458-60.

33.- ROMERO J J, PÉREZ E, FRANKENA K. Effect of a killed whole Neospora caninum tachyzoite vaccine on the crude abortion rate of Costa Rican dairy cows under field conditions. Vet Parasitol 2004; 123: 14959.

34.- MOORE D P, LEUNDA M R, ZAMORANO P I et al. Immune response to Neospora caninum in naturally infected heifers and heifers vaccinated with inactivated antigen during the second trimester of gestation. Vet Parasitol 2005; 130: 29-39.

35.- ANDRIANARIVO A G, ANDERSON M L, ROWE J $\mathrm{D}$, et al. Immune responses during pregnancy in heifers naturally infected with Neospora caninum with and without immunization. Parasitol Res 2005; 96: 2431

36.- WEISS L M, MA Y F, HALONEN S, et al. The in vitro development of Neospora caninum bradyzoites. Int J Parasitol 1999; 29: 1713-23.

Acknowledgment: D.P. Moore thanks Dr. Douglas Hodgins (Ontario Veterinary College/U. of Guelph, Canada) and Dr. Carlos Campero (INTA, Balcarce, Argentina) for critical review and helpful comments. 